at low speeds, yet fall off sometimes even below the full-load value (which remains nearly constant) at high speeds. One may perhaps complain that at one point the author is not quite precise in his explanation as to why heat transfer from a cylinder wall to a turbulent charge does not increase pro rata with the scrubbing velocity, and, at another, no definition is given of "conventional velocity", the abscissa of one of the curves; but these are very small details. It is a paper pleasantly written, the reading of which should throw considerable light on the hidden processes of the compression-ignition engine.

$$
181=
$$

\section{TRAINING FOR MANAGEMENT}

$\mathrm{A}$ $\mathrm{T}$ a recent cócerence at Ashorne Hill, Leamington, which was organised by the West Midlands group of thoritish Association for Commercial and Industrial Sducation, the subject of training for managetnd was examined by means of lecture and discassion.

Atloducing the first session, Sir Charles Bartlett, mandging director of Vauxhall Motors, reminded the conference that management was not an end in itself but a vital weapon in a nation's struggle to maintain its existence, a struggle in which failure meant utter disaster. The first speaker, Mr. D. B. Brown, managing director of the Glacier Metal Co., analysed the process of management into three stages. First, the making of policy; secondly, the decision on applying policy; and, thirdly, the execution of policy. The manager, Mr. Brown suggested, was the executive; but in the first two stages he had no more right than the other two main interests concerned, the producer and the consumer. He should see that decisions at these stages were shared with them. Although the consumer could not be consulted directly, his wishes normally were expressed through the working of the market. The producer, the man in the works, can and should be consulted. He must feel that his opinion and individuality were respected. For the third or executive stage the manager must possess real power that comes from acting with consent.

In the discussion Sir Charles Bartlett referred to other elements in responsible leadership, among them the need to lead by example. Speaking of sharing responsibilities, he said that joint consultation was sterile unless there was some real devolution of authority. In his own company, for example, authority to deal with absenteeism had been given to a joint committee and had resulted in an absence figure of less than 1 per cent.

Introducing the second session, Sir Graham Cunningham stated that management training could at least be accelerated by systematic study. 'The theoretical training should include the manager's preliminary education, which might end at fifteen, eighteen or twenty-one years; some training to enable him to grasp the ideas of his time; and the acquisition of knowledge of the processes and the organisation of his particular firm. The speaker in this session, Mr. N. C. Rimmer, considered the shortcomings of many of the existing methods of theoretical training for management and pointed to two things which must be done as part of this training. First, there was the study of responsibilities and functions in the process of getting a job done; secondly, there was the study of how orders should be given, to whom, by whom, and by what method.
The speaker at the third session was Mr. John Ryan, vice-chairman of the Metal Box Co., who quoted twelve attributes which had been postulated as necessary for a business leader: physical and nervous energy; enthusiasm ; alertness ; imagination-including a lively curiosity and interest in new ideas ; character-among other things he must be truthful, temperate, and sincere ; sound judgment ; courage-especially to take decisions which could not please everybody; sense of humour; the ability to listen; a knowledge of human nature, with the ability to see through other people's eyes; and finally a sense of purpose and belief in his job.

Though almost all these qualities could be developed, Mr. Ryan pointed out that some were innate, and careful selection must precede training. The training of potential managers in the works would involve close surveillance by higher management. After training in administrative work the man should be given a job of his own as soon as possible, while training in specific subjects should continue. His training should also include attendance at conferences, both national and international.

In the fourth session the speaker was Prof. T. $H$. Marshall, who read a paper on the "Manager and the Community". In looking at management from the outside, Prof. Marshall stated that it was not always possible to distinguish between direction and management functions; the former, dealing with policy, was more relative to the major issues. This subject was fundamental in dealing with problems of social order, distribution and property, and distinction of class. Considering the actual position of management to-day, Prof. Marshall said that two questions to be answered were whether society regarded management power as legitimate, and what the responsibilities of management were-to whom and through whom.

Turning to the nature of management responsibility, Prof. Marshall traced its four directions : to the owners, or shareholders in the business; to the State, through the Government; to the customer or consumer; and to the worker in industry. If he had to place one of these first, he would choose the consumer; his interests were generally shared by the other three, whose individual interests might conflict. There was no machinery, he pointed out, for resolving such conflicts, no set of rules to be referred to. This situation, however, was common in the older professions-medicine, for example, with the conflicts, of which there were recent examples, between its responsibilities towards its patients, the community and its own science. Such conflicts were solved by building up a code of professional ethics, to which they could be individually referred. In Prof. Marshall's view, management needed a similar professional code of ethics, though it did not need the same rigid system of controlling entry and prescribing qualifica. tions as for the professions.

Summarizing the conference, Mr. Ronald Ogden, general secretary of the British Association for Commercial and Industrial Education, stressed the necessity to realize that, whether managers like it or not, industrial democracy had come to stay, and that they must tackle the problems involved in a realistic manner. Joint consultation was one of the ways of tackling them; but joint consultation if adopted must be introduced sincerely on the part of management, and must not be looked upon as mere 'window dressing'.
T. H. HAWKINS 